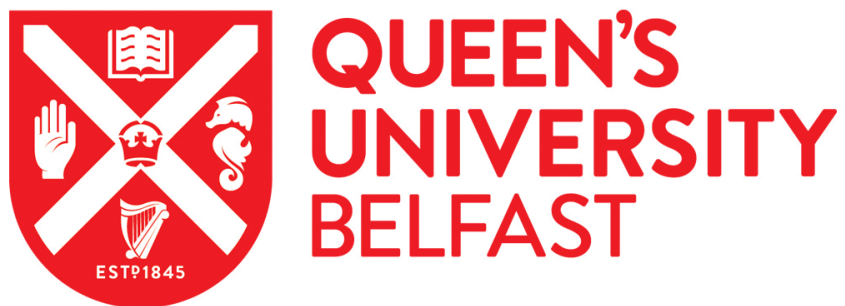

\section{'Technologies of Reflexivity': Generating Biopolitics and Institutional Risk to Supplement Global Public Health Security}

Flear, M. (2017). 'Technologies of Reflexivity': Generating Biopolitics and Institutional Risk to Supplement Global Public Health Security. European Journal of Risk Regulation, 8(4), 658-685. https://doi.org/10.1017/err.2017.62

\author{
Published in: \\ European Journal of Risk Regulation
}

Document Version:

Peer reviewed version

Queen's University Belfast - Research Portal:

Link to publication record in Queen's University Belfast Research Portal

\section{Publisher rights}

(O2017 Cambridge University Press. This work is made available online in accordance with the publisher's policies. Please refer to any applicable terms of use of the publisher.

\section{General rights}

Copyright for the publications made accessible via the Queen's University Belfast Research Portal is retained by the author(s) and / or other copyright owners and it is a condition of accessing these publications that users recognise and abide by the legal requirements associated with these rights.

Take down policy

The Research Portal is Queen's institutional repository that provides access to Queen's research output. Every effort has been made to ensure that content in the Research Portal does not infringe any person's rights, or applicable UK laws. If you discover content in the Research Portal that you believe breaches copyright or violates any law, please contact openaccess@qub.ac.uk. 


\title{
'Technologies of Reflexivity': Generating biopolitics and institutional risk to supplement global public health security
}

\begin{abstract}
Mark L Flear ${ }^{*}$
Critiques of global public health security (GPHS) and proposed solutions tend to overlook the potential of the individuals and groups that are subject to and governed by GPHS - 'the governed' - to contribute their 'on the ground' knowledge and experience to decision-making in order to improve regulatory responses. This article argues for the development of a more reflexive approach as a way of ensuring the epistemic integration of these knowledges with the scientific-technical knowledges that currently dominate decision-making processes. I identify human rights as the conceptual lens that is most likely to enable reflexivity by the governed and regulators, and understanding and communication between them. The governed can use perceived or actual breaches of human rights to articulate 'on the ground' knowledges as institutional risks to reputation and standing and, in turn, threaten the production and legitimation of organisational identity, socio-political orders and projects of rule. The particular sensitivity of regulators to these risks could compel epistemic integration. This more reflexive approach to GPHS promises to improve the knowledge base, efficacy, accountability and legitimacy of decision-making at multiple levels: WHO, EU, national and 'on the ground'.
\end{abstract}

Key words: Global Public Health Security, Risk, Reflexivity, Knowledge, Human Rights, WHO, EU

\section{Introduction}

Attempts to create a safer and more secure future abound, particularly in respect of highly uncertain risks that threaten to have a particularly grave or even catastrophic impact. Indeed, these attempts have, it seems, never been so prominent or important, not simply to safeguarding health, life and the economy, but also to the legitimacy of formally accountable actors. ${ }^{1}$ Global public health security (GPHS) is one key example of these attempts and their importance. The World Health Organisation (WHO), the European Union (EU) and individual states, have made GPHS central to their approach towards diverse threats to public health, and through it the production and legitimation of their identities, socio-political orders and projects of rule.

GPHS was defined in the World Health Organisation's (WHO's) The World Health Report 2007: A Safer Future: Global public health security in the 21st century (A Safer Future):

Public health security is... the activities required, both proactive and reactive, to minimise vulnerability to acute public health events that endanger the collective health of national populations. Global public health security widens this definition to include acute public health events that endanger the collective health of populations living across geographical regions and international boundaries....

\footnotetext{
* Queen's University Belfast. Many thanks to the participants in the seminar 'Germs, Bioterrorism and Chemical Attacks: Internal and External EU Security Perspectives', Brussels, 21-22 November 2016, where the earliest draft of this article was presented and to James Revill for his comments as discussant. Thanks to the editors of this special issue, the peer reviewers and to Richard Ashcroft, Colm O'Cinneide, Markus Frischhut, Colin Harvey and Anne-Marie McAlinden for their comments and suggestions.

${ }^{1}$ For discussion see, for example: S Jasanoff, The Ethics of Invention: Technology and the human future (Norton \& Company 2016).

${ }^{2}$ WHO, The World Health Report 2007: A Safer Future: Global public health security in the 21st century (WHO 2007), 1. Emphasis added.
} 
This definition has been so successful that rare diseases like Ebola or Zika and emerging infectious diseases like pandemic influenza ${ }^{3}$ nowadays tend to be considered alongside HIV/AIDS ${ }^{4}$ and the use of chemical, biological, radioactive and nuclear weapons by terrorist organisations or rogue states. ${ }^{5}$ Together these are understood as threats that must be regulated in order to maintain security.

However, as in other attempts to govern the future through action in the present, both GPHS and the actors that produce and employ it in and through their regulation ${ }^{6}$ have faced acute and mounting criticism of its efficacy, and challenges to their accountability and legitimacy. In respect of GPHS the most prominent example is the WHO's handling of the Ebola outbreak in west Africa, particularly Guinea, Liberia and Sierra Leone. The Director General at the time waited four months after Médecins Sans Frontières (MSF) announced an unprecedented outbreak to declare a Public Health Emergency of International Concern (PHEIC) under the International Health Regulations 2005 (IHR 2005) ${ }^{7}$ on 8 August 2014. In July 2015 the WHO's Ebola Interim Assessment Panel, which was chaired by the former Ethiopian health minister Dr Tedros Adhanom Ghebreyesus, gave a damning verdict.

Most significantly for this article, the Panel noted inter alia that the WHO's 'technical, normative culture... [was not] well-suited to challenging its Member States', ${ }^{8}$ some of which were slow to report outbreaks for fear that a PHEIC would lead others to implement travel and trade restrictions beyond the scope of the WHO's recommendations and in contravention of Article 43 IHR 2005 (over 40 countries did). ${ }^{9}$ As for the WHO's decision-making in relation to declaring a PHEIC, the Panel's report proclaimed that urgent warnings like MSF's 'either did not reach senior leaders or senior leaders did not recognise their significance' ${ }^{10}$ The Panel was also 'surprised and dismayed by serious gaps...in terms of engaging with the local communities' ${ }^{11}$ particularly in the early stages of the outbreak.

The Ebola outbreak was only the most recent challenge to this GPHS as an attempt to create a safer future. The 2009 outbreak of pandemic influenza H1N1 did not transpire on anything like the imagined scale. This led the Parliamentary Assembly of the Council of Europe to criticise the WHO for declaring a PHEIC, weaknesses in transparency, and the EU and national authorities for their stockpiling of medical interventions to deal with the potential threat from outside Europe. Stockpiling produced a 'distortion of priorities of public health services across Europe, [and the] waste of large sums of public

\footnotetext{
${ }^{3}$ Avian influenza or A/H5N1.

${ }^{4}$ Human Immunodeficiency Virus and Acquired Immune Deficiency Syndrome. For discussion, see: S Elbe, 'Should HIV/AIDS be Securitised? The Ethical Dilemmas of Linking HIV/AIDS and Security' (2006) 50(1) International Studies Quarterly 119.

${ }^{5}$ Gro Harlem Brundtland, 'Global Health and International Security' (2003) 9(4) Global Governance 417; D Fidler, SARS, Governance and the Globalisation of Disease (Palgrave Macmillan 2004); LO Gostin, 'Pandemic Influenza: public health preparedness for the next global health emergency' (2004) 32(44) Journal of Law, Medicine and Ethics 565; D Heymann, 'Evolving Infectious Disease Threats to National and Global Security', in L Chen and others (eds), Global Health Challenges for Human Security (Harvard UP 2003); G Prins, 'AIDS and Global Security' (2004) 80(5) International Affairs 931.

${ }^{6}$ Black defines regulation as 'the intentional use of authority to affect behaviour of a different party according to set standards, involving instruments of information-gathering and behaviour modification' (J Black, 'Critical Reflections on Regulation' (2002) 27 Australian Journal of Legal Philosophy 1).

${ }^{7}$ International Health Regulations (WHA58/2005/REC/1, 23 May 2005).

${ }^{8}$ WHO, Report of the Ebola Interim Assessment Panel (WHO 2015), 13. Emphasis added.

${ }^{9}$ This requires all Member States to behave with appropriate responsibility towards the international community in the adoption of travel and trade restrictions. Moreover, this provision also requires that Member States are to inform the WHO of additional measures and to provide a scientific rationale and justification that can be shared among Member States (Article 43(3)). The WHO may request a Member State to reconsider the application of additional measures (Article 43(4)).

${ }^{10} \mathrm{WHO}$, note 8 above, 12. Emphasis added.

${ }^{11}$ Ibid, 20. Emphasis added.
} 
money'. ${ }^{12}$ This criticism was echoed before inter alia the Council of the $\mathrm{EU}^{13}$ and the European Parliament ${ }^{14}$ in respect of EU level responses. Despite the criticisms of GPHS, its core features scientific-technical knowledge as the basis for planning a surge of vertical or disease-specific and treatment-based interventions, so as to ensure the resilience of essential infrastructures so they 'bounce back' to their original state after an emergency ${ }^{15}$ - have remained intact. Nevertheless, the official criticisms underscore the way in which the (mis)handling of attempts to manage highly uncertain threats and create a safer future can produce institutional risks i.e. a risk to standing and reputation that in turn generate pressure for action.

The Ebola Interim Assessment Panel also noted the importance of transforming the WHO's culture and delivery and that 'it will need to be held accountable to ensure that this transformation is achieved'. ${ }^{16}$ Nevertheless, little more is said by either the Panel, in official responses to the 2009 outbreak of pandemic influenza H1N1, or in scholarly discussion on GPHS, about the potential role of the governed to improve accountability or legitimacy, the specific role of their 'on the ground' knowledges or the way in which they might contribute to decision-making. ${ }^{17}$ In this article I proffer answers to the following questions. Why might the integration of 'on the ground' knowledges with the scientifictechnical knowledges that dominate GPHS be important? How might those knowledges be generated and contribute towards decision-making? How might regulator's sensitivity to institutional risks be leveraged to facilitate epistemic integration? What conceptual or hermeneutic resources are available to facilitate this? Overall, I argue for the take-up of 'on the ground' knowledges in decision-making through new technologies that will provide a supplement to GPHS. The Panel's report is referred to throughout the article, since its critique of the implementation of GPHS in some of the most vulnerable settings throws the normative concerns discussed into stark relief. ${ }^{18}$

Through the conceptual perspective outlined in the next section, and which informs the subsequent discussion, I identify some of the core components of two key current technologies of global public health regulation - prevention and health promotion and GPHS - and the technologies of reflexivity developed in this article. The core components include the respective risk rationalities, ${ }^{19}$ related forms of knowledge and the actors that produce and interpret them. Prevention and health promotion are mentioned in brief in order to situate GPHS, underscore its necessity and explain its key features. Drawing on literatures on risk, I explain that it is the scientific-technical framing of GPHS that underlies the lack of recognition of 'on the ground' knowledges noted by the Ebola Interim Assessment Panel. In addition to an outline of public health regulation at the global level, brief reference is also made to the

\footnotetext{
${ }^{12}$ Council of Europe, The Handling of the H1N1 Pandemic: More transparency needed (CoE 2010), Draft Resolution A1. See further: Council of Europe, Resolution 1749, 24 June 2010; Council of Europe, Recommendation 1929, 24 June 2010. Also see: D Cohen and P Carter, 'WHO and the Pandemic Flu "Conspiracies"' (2010) 340 British Medical Journal c2912.

${ }^{13}$ Council of the EU, Council Conclusions on Lessons Learned from the A/H1N1 Pandemic - Health Security in the European Union, Brussels, 13 September 2010.

${ }^{14}$ European Parliament Resolution of 8 March 2011 on Evaluation of the Management of H1N1 Influenza in 2009-2010 in the EU (2010/2153(INI)) OJ C 199E/7.

${ }^{15}$ Resilience has been described as the "capacity of a system to absorb disturbance and reorganise while undergoing change so as to still retain essentially the same function, structure and feedbacks, and therefore identity' - see: CSR Folke and others, 'Resilience Thinking: Integrating resilience, adaptability and transformability' (2010) 15(4) Ecology and Society 20 (available at: http://www.ecologyandsociety.org/vol15/iss4/art20/). Emphasis added.

${ }^{16} \mathrm{WHO}$, note 8 above, 5. Emphasis added.

${ }^{17}$ Prominent recent examples of this being: SE Davies and others, Disease Diplomacy: International norms and global health security (John Hopkins UP 2015); B Bennett and SE Davies (eds), 'Special Issue: Global health governance of public health emergencies' (2017) 25(2) Medical Law Review. On the lack of engagement with citizen participation in public health more generally, see: ML Flear, Governing Public Health (Hart 2015), Ch 1 'Context, Approach and Overview', 15-20.

${ }^{18}$ See, for example: E Cloatre, Pills for the Poorest (Palgrave Macmillan 2013).

${ }^{19}$ Rationality is described as 'a way of doing things that...[is] oriented to specific objectives and that...[reflects] on itself in characteristic ways': N Rose and others, 'Governmentality' (2006) 2 Annual Review of Law Society and Science 83, 84.
} 
EU. ${ }^{20}$ It is not possible to provide a more extensive overview of GPHS and its operationalisation in individual countries within a single article. Nevertheless, reference to the WHO and the EU enables me to underline the way in which GPHS is embedded within and increasingly tied to wider processes of governing. Further, at least outside EU studies on (public) health law, ${ }^{21}$ the EU's role in this area has hitherto been largely overlooked. ${ }^{22}$ This article therefore also contributes towards an understanding of the EU's significance to GPHS and the significance of GPHS to the EU and the WHO in the servicing of their respective legitimacy needs. ${ }^{23}$ In the final part of the next section I reflect on the way in which this framing valorises those in possession of the expertise to understand and interpret these knowledge forms, and marginalises and subordinates those that do not i.e. those governed by GPHS, and their 'on the ground' knowledges.

I outline those knowledges at the start of the third section, before turning to discuss the potential of the governed to contribute them towards decision-making. In order to realise that potential, I reflect on the discussion in the previous (second) section and pinpoint the importance of risk to regulatory frameworks such as GPHS. Subsequently, I explain how this could provide a 'way in' to decision-making. The 'way in' is via regulatory sensitivity to and reflexive engagement with institutional risks to standing and reputation and, in turn, organisational identity, socio-political order and projects of rule. Reflexivity is the capacity of individuals, groups and institutions to engage in the automatic monitoring of social reality so as to (re)shape the terms constitutive of it (or indeed themselves). ${ }^{24}$

In the final part of the third section, I reflect further on the previous (second) section, and in particular the regulatory architecture, and identify human rights as the conceptual or hermeneutic resource, foundation and lens to enable reflexivity. I explain how the latter can be used to forge technologies that make use of the 'way in' so as to facilitate epistemic integration. Reflexive engagement by the individuals and groups comprising the governed can engender the gathering and production of 'on the ground' knowledges. In order to ensure the take up of these knowledges and their integration with scientific-technical knowledge in decision-making, I suggest that human rights can be used to (re)articulate the knowledges as claims and generate institutional risks that regulators reflexively notice, integrate within decision-making and act upon. Technologies of reflexivity are, in short, an attempt to reframe, reimagine and reassemble various components in order to supplement technocratic regimes such as GPHS, and improve their knowledge base, efficacy, accountability and legitimacy.

\section{Regulating global public health security: risk rationalities, knowledge and key actors in its construction and interpretation for decision-making}

\section{Prevention and health promotion and the regulation of established threats}

The discovery of 'population' and statistics to track its size and patterns through a body of archivalstatistical knowledge made it possible to measure the incidence of disease through epidemiology, the

\footnotetext{
${ }^{20}$ Where there is reference to the EU, the focus is on the EU's regulatory order, which is one level of the multilevel system of governance. Within that system the EU level interacts with a range of other regulatory orders including those at the national level. See further: L Hooghe and G Marks, Multilevel Governance and European Integration (Rowman \& Littlefield 2001).

${ }^{21}$ Flear, note 17 above; M Frischhut and S Greer, 'EU Public Health Law and Policy - Communicable Diseases' in TK Hervey and others (eds), Research Handbook on EU Health Law and Policy (Edward Elgar 2017); TK Hervey and JV McHale, European Union Health Law (CUP 2015), especially Ch 15 'Risk: tobacco, food, alcohol'.

22 See: Bennett and Davies, note 17 above.

${ }^{23}$ For discussion, see: Flear, note 17 above.

${ }^{24}$ As discussed in modernisation theory: U Beck, Risk Society: Towards a new modernity (Sage 1986); A Giddens, The Constitution of Society (Polity 1984); A Giddens, Modernity and Self-Identity (Polity 1991); N Luhmann, Observations on Modernity (Stanford UP 1998). Foucault did not have a theory of reflexivity, but for such an addition to his thinking see: J Butler, The Psychic Life of Power (Stanford UP 1997).
} 
science of public health. ${ }^{25}$ This in turn led to a new field of power/knowledge, a term that denotes the way in which changes in knowledge help to provide the basis for the production and exercise of governmental power and control. Knowledge is essentially "the "know how" that makes government possible ${ }^{26}$ and it is produced and interpreted by those with the necessary expertise.

These developments led to the displacement of the protection of territory and sovereignty as the dominant understanding of security. As Foucault explained, security became understood as being about regulating the dangers and threats attendant to freedom understood as the movement of 'both people and things' ${ }^{27}$ Security is about responding 'to a reality in such a way that...[it] cancels out the reality to which it responds...regulates it'. ${ }^{28}$ Moreover, these developments gave rise to governmentality. ${ }^{29}$ The various knowledges, discourses, techniques, processes and practices that regulate everyday life, including law, are underpinned, orientated, directed and made to work together as technologies by particular rationalities. ${ }^{30}$ Throughout this article I examine how GPHS is a particular example of the transformation and integration of law and regulation within governmentality.

Prevention is the risk rationality that has long been central to public health regulation. Risk is a form of attention to the world that constructs targets of regulation, renders them knowable and creates the basis for regulatory action, and it has been taken up in diverse fields. ${ }^{31}$ Nothing is a risk in itself, but instead risk is co-constituted through a field of knowledge and regulatory processes. ${ }^{32}$ Risk shapes and frames perceptions of problems and their solutions, such as prevention and health promotion efforts. These occur through technologies - see Figure: 1 - that regulate dangers or threats not only at the national level, but since the constitution of 'population' as a global phenomenon, ${ }^{33}$ also at the global level. ${ }^{34}$ For instance, the WHO adopted the Declaration of Alma-Ata and a number of other important formal statements that reaffirmed health as a human right that includes health care or treatment and action on the socio-economic determinants of health, including the quality of food, environmental protection, the

\footnotetext{
${ }^{25}$ I Hacking, The Taming of Chance (CUP 1990). Also see: A Desrosières, The Politics of Large Numbers: A history of statistical reasoning (Harvard UP 1998); WN Espeland and ML Stevens, 'A Sociology of Quantification' (2008) 49(3) European Journal of Sociology 401; T Porter, Trust in Numbers: The pursuit of objectivity in science and public life (Princeton UP 1995).

${ }^{26}$ N Rose and P Miller, 'Political Power Beyond the State: problematics of government' (1992) 43(2) British Journal of Sociology 172, 178.

${ }^{27}$ M Foucault, Security, Territory, Population: Lectures at the Collège de France, 1977-1978 (Palgrave

Macmillan 2007), 48-49.

${ }^{28}$ Ibid, 47.

${ }^{29} M$ Dean, Governmentality: power and rule in modern society, $2^{\text {nd }}$ edn (Sage Publications 2009).

${ }^{30}$ For discussion of 'technology' see: Flear, note 17 above, Ch 1 'Context, Approach and Overview', 6, 20-22.

${ }^{31}$ In general see: F Ewald, 'Insurance and Risk' in G Burchell and others (eds), The Foucault Effect. Studies in governmentality (University of Chicago Press 1991); F Ewald and S Utz, 'The Return of Descartes' Malicious Demon: An outline of a philosophy of precaution' in T Baker and J Simon (eds), Embracing Risk: The changing culture of insurance and responsibility (University of Chicago Press 2002). More generally see, for example: RV Ericson, Crime in an Insecure World (Polity 2007); L Zedner, 'Fixing the Future? The Pre-emptive Turn in Criminal Justice' in B McSherry and others (eds), Regulating Deviance: The redirection of criminalisation and the futures of criminal law (Hart 2009).

${ }^{32} \mathrm{~S}$ Jasanoff, 'The Idiom of Co-Production' in S Jasanoff (ed), States of Knowledge: the co-production of science and the social order (Routledge 2004); S Jasanoff and S-H Kim, Dreamscapes of Modernity: Sociotechnical imaginaries and the fabrication of power (University of Chicago Press 2015).

${ }^{33}$ D Reubi, 'A Genealogy of Epidemiological Reason: Saving lives, social surveys and global population' (2017) doi:10.1057/s41292-017-0055-2.

${ }^{34} \mathrm{~T}$ Brown and others, 'Critical Interventions in Global Health: governmentality, risk and assemblage' (2012) 102(5) Annals of the Association of American Geographers 1182; W Larner and W Walters, Global Governmentality: Governing international spaces (Routledge Press 2004); M de Larrinaga and MG Doucet, Security and Global Governmentality (Routledge 2010).
} 
provision of public housing and welfare benefits. ${ }^{35}$ Law, specifically the content of the right to health ${ }^{36}$ and health-related rights, ${ }^{37}$ has supported these developments. ${ }^{38}$

Figure: 1 - Technologies of global public health regulation: prevention and health promotion, security (GPHS), and reflexivity

\begin{tabular}{|l|l|l|l|}
\hline & $\begin{array}{l}\text { Prevention and health } \\
\text { promotion }\end{array}$ & Security & Reflexivity \\
\hline Key target & $\begin{array}{l}\text { Established public health } \\
\text { threats }\end{array}$ & $\begin{array}{l}\text { Rare or emerging } \\
\text { public health threats }\end{array}$ & $\begin{array}{l}\text { Distortions in } \\
\text { attention, distribution } \\
\text { of resources and } \\
\text { vulnerability }\end{array}$ \\
\hline $\begin{array}{l}\text { Rationality of risk } \\
\text { regulation }\end{array}$ & Prevention & Preparedness & Reflexivity \\
\hline Knowledge & Statistics & $\begin{array}{l}\text { Statistics and } \\
\text { Imaginative } \\
\text { Enactment }\end{array}$ & $\begin{array}{l}\text { Statistics, imaginative } \\
\text { enactment and 'on the } \\
\text { ground' knowledges } \\
\text { (i.e. place, history, } \\
\text { culture and } \\
\text { experience) }\end{array}$ \\
\hline $\begin{array}{l}\text { Key actors in the } \\
\text { construction and } \\
\text { interpretation of } \\
\text { knowledge }\end{array}$ & Experts & $\begin{array}{l}\text { Experts and the } \\
\text { governed }\end{array}$ \\
\hline Interventions & $\begin{array}{l}\text { Prevention and health } \\
\text { promotion }\end{array}$ & $\begin{array}{l}\text { Resilience of essential } \\
\text { infrastructures }\end{array}$ & $\begin{array}{l}\text { Adjustments in other } \\
\text { technologies }\end{array}$ \\
\hline
\end{tabular}

\footnotetext{
${ }^{35}$ WHO Alma-Ata Declaration on Primary Health Care 1978; WHO Ottawa Charter for Health Promotion 1986; Adelaide Recommendations on Healthy Public Policy 1988; Rio Political Declaration on Social Determinants of Health 2011.

${ }^{36}$ Or more accurately 'the right of everyone to the enjoyment of the highest attainable standard of physical and mental health' found in Article 12 International Covenant on Economic, Social and Cultural Rights (16 December 1966, entered into force 3 January 1976) 993 UNTS 3. In the European regional human rights system, Articles 11 and 13 European Social Charter (Revised) (3 May 1996, entered into force 1 July 1999, 2151 UNTS 277, ETS 163) are important in that they relate to the treatment of illness. Specifically, Article 13 provides that 'anyone without adequate resources has the right to social and medical assistance'. Article 11 provides that 'everyone has the right to benefit from any measures enabling him to enjoy the highest standard of health attainable' including through measures which 're-move as far as possible the causes of ill-health' and 'prevent as far as possible epidemic, endemic and other diseases, as well as accidents'. As for the European Convention on Human Rights and Fundamental Freedoms (4 November 1950, entered into force 3 September 1953) ETS 5, signature states are required to take reasonable steps to protect life under Article 2 on the right to life (Osman v UK [1999] 1 FLR 193).

${ }^{37}$ The right to adequate food, clothing and housing, the right to freedom from hunger, and the right to environmental and industrial hygiene are found in Articles 11 and 12 ICESCR. Other rights, including the right to liberty and security of the person, freedom from coerced labour, liberty of movement, freedom of thought, conscience and religion and freedom from discrimination, are found in Articles 4, 8, 9, 12, 18 and 26 International Covenant on Civil and Political Rights (16 December 1966, entered into force 23 March 1976) 999 UNTS 171 (ICCPR). In the European regional human rights system, the Article 2 European Convention on Human Rights and Fundamental Freedoms (4 November 1950, entered into force 3 September 1953) ETS 5 on the right to life provides that signature states are required to take reasonable steps to protect life (Osman $v U K$ [1999] 1 FLR 193). For discussion see: J Tobin, The Right to Health in International Law (OUP 2012); B Toebes and others (eds), Health and Human Rights in Europe (Intersentia 2012).

${ }^{38}$ In particular through, Committee on Economic, Social and Cultural Rights, 'General Comment No 14: The right to the highest attainable standard of health (art 12)' (11 August 2000) UN Doc E/C.12/2000/4, which spells out the content.
} 
EU level action includes efforts to address the social determinants of undefined major public health problems through prevention and health promotion, including by fostering cooperation with third countries and international public health organisations. ${ }^{39} \mathrm{EU}$ action is underpinned and justified by Article 168(1) Treaty on the Functioning of the EU (TFEU), which provides an obligation to ensure a high level of human health protection in the definition and implementation of EU policies and activities i.e. a health in all policies approach. This obligation is a more specific instantiation of the cross-cutting obligation found in Article 9 TFEU and Article 35 EU Charter of Fundamental Rights (EUCFR) on the right to health care, the final portion of which repeats and takes over from Article 168(1) TFEU. ${ }^{40}$ Prevention and health promotion are the key - even the archetypal - technologies of public health, and they provide a necessary contrast to GPHS and the rationality that underpins its technologies, preparedness. I turn now to discuss the latter in greater depth, before turning to commence reflection on the implications of the core features of these technologies for the governed and the place of their knowledges within decision-making.

\section{Preparedness and the regulation of rare and emerging threats}

However, a cluster of rare and emerging threats to public health, including infectious diseases and perhaps especially the 9/11 terrorist attacks in New York and elsewhere, meant that the existing body of archival-statistical knowledge provided a weak basis for prediction and, therefore, the rationality and techniques of prevention became of less use to regulation. ${ }^{41}$ Consequently, planning or so-called imaginative enactment as the form of knowledge and the rationality and techniques of preparedness and response were adopted to ensure that a developing emergency could be regulated despite high levels of uncertainty. ${ }^{42}$ The techniques of preparedness target rare and emerging public health threats as risks, thereby subjecting them to regulation and rationality. ${ }^{43}$ The aim is to strengthen health preparedness and response globally in order to address 'all hazards' ${ }^{44}$ Preparedness entails using planning to buildup the resilience of essential infrastructures, including containment measures, vigilance and surveillance, ${ }^{45}$ so that they can respond to and rebound from a health emergency.

As Collier and Lakoff explain, preparedness 'demands that experts constantly assess the vulnerability of [these] vital systems and the readiness to respond to, and recover from, events that threaten them'. ${ }^{46}$ In this way the circulation of population and things in the economy is protected indirectly or reflexively by, as Dean put it, 'securing the mechanisms of government' ${ }^{47}$ and governing at a distance through a

\footnotetext{
${ }^{39}$ Article 168(3) TFEU.

${ }^{40}$ According to the Explanatory Notes for the EUCFR in respect of Article 35 - see: Explanations Relating to the Charter of Fundamental Rights (2007/C 303/02) OJ C 303/17.

${ }^{41}$ See also, discussion of 'known unknowns' (those risks that we know we don't know about) and 'unknown unknowns' (those risks that we don't know that we don't know about) in: Zedner, note 31 above.

${ }^{42}$ More generally, see: RV Ericson and A Doyle, Uncertain Business: Risk, insurance and the limits of knowledge (University of Toronto Press 2004); A Lakoff, 'From Population to Vital System' in A Lakoff and SJ Collier (eds), Biosecurity Interventions: Global health and security in question (Columbia UP 2008); P O’Malley, Risk, Uncertainty and Government (Glasshouse Press 2004).

${ }^{43}$ M Douglas and A Wildavsky, Risk and Culture: An essay on the selection of technical and environmental dangers (University of California Press 1982); N Luhmann, Risk: A sociological theory (de Gruyter 1993).

${ }^{44}$ In general see: DP Fidler and LO Gostin, Biosecurity in the Global Age: Biological weapons, public health, and the rule of law (Stanford UP 2007); S Hinchcliffe and N Bingham, 'Securing Life: the emerging practices of biosecurity' (2008) 40(7) Environment and Planning A 1534; F Lentzos, 'Rationality, Risk and Response: A research agenda for biosecurity' (2006) 4(1) BioSocieties 453.

${ }^{45}$ A focus noted as transferred from the United States' Centre for Disease Control to the WHO and globally by one of its experts, see: H Ashraf, 'David Heymann - WHO's Public Health Guru' (2004) 4(12) The Lancet Infectious Diseases 785. For the roots of this approach, see: DH Henderson, 'Surveillance Systems and Intergovernmental Cooperation' in S Morse, Emerging Viruses (OUP 1993).

${ }^{46}$ S Collier and A Lakoff, 'Vital Systems Security' (2007) ARC Working Paper No 2, 3. Emphasis added. Also see: A Lakoff, 'Real-time Biopolitics: The actuary and the sentinel in global public health' (2015) 44(1) Economy and Society 40; SL Roberts and S Elbe, 'Catching the Flu: Syndromic surveillance, algorithmic governmentality and global health security’ (2017) 48(1) Security Dialogue 46.

${ }^{47}$ Dean, note 29 above, 226. Emphasis added.
} 
cycle of preparedness planning and response. An emergency is alerted and identified through techniques of risk assessment involving monitoring and surveillance. Subsequently there is a turn to risk management through a rapid response involving a surge of measures such as kits, antivirals and treatments allocated by triage. Containment can also involve limitations on travel, embargoes and quarantine. Risk communication between experts and those affected or 'at risk' is important throughout and is aimed at shaping behaviours 'on the ground', building trust and improving the efficacy of interventions. The overall goal of preparedness and response is to ensure the containment of threats 'at source', essentially externalising threats outside the countries of the West. ${ }^{48}$ This also shifts the responsibilities for threat management to other (non-Western) countries, but with the chief goal of minimising disruption to the economy and protecting the interests of richer (Western) countries.

Although GPHS was formally instantiated in 2007's A Safer Future, the technology itself - see Figure: 1 for its core components - comprises a range of actors, sites and fora. At the global level GPHS includes the Global Outbreak Alert and Response Network (often simply referred to as GOARN). This was established by WHO in 2000 and comprises agencies and technical institutions, including the EU's European Centre for Disease Control (ECDC). ${ }^{49}$ Beyond the United Nations system there is the Global Health Security Initiative, which is dominated by Western countries and with which the EU cooperates. ${ }^{50}$ The most important legal component of GPHS is the IHR 2005, which replaced the IHR 1969. Adding to the few brief points made in the introduction to this article, the IHR 2005 takes an " "all risks" approach ${ }^{51}$ to infectious diseases and aims to:

'prevent, protect against, control and provide a public health response to the international spread of disease in ways that are commensurate with and restricted to public health risks, and which avoid unnecessary interference with international traffic and trade, ${ }^{52}$

Public health, then, is closely tied to protecting the global economy i.e. by regulating and optimising the global flows of people and things. ${ }^{53}$ The IHR 2005 significantly expanded expectations of states in the face of public health emergencies and required them to improve their core capacities to detect and contain them. States are obligated to notify the WHO of events within their territories that may constitute a 'public health emergency of international concern' (PHEIC) declared by the WHO Director General. ${ }^{54}$ In respect of diseases and other public health threats the WHO primarily undertakes global risk assessments that enable more local level risks assessments. The WHO also engages in risk communication and provides guidance on interventions through risk management (consistent with the IHR 2005) ${ }^{55}$ This centralisation of scientific-technical knowledge valorises those deemed in possession of the expertise to interpret it.

\footnotetext{
${ }^{48}$ This approach stems in large part from: NM Ferguson and others, 'Strategies for Containing an Emerging Influenza Pandemic in Southeast Asia' (2005) 437 Nature 209. Also see: IM Longini and others, 'Containing Pandemic Influenza at the Source' (2005) 309 Science 1083e1087.

${ }^{49} \mathrm{~J}$ Weinberg, 'Responding to the Global Challenge of Infectious Disease' in M McKee and others (eds), International Co-operation in Health (OUP 2001).

${ }^{50}$ See 'Global Health Security Initiative', http://www.ghsi.ca/english/index.asp.

${ }^{51}$ DP Fidler and LO Gostin, 'The New International Health Regulations: An historic development for international law and public health' (2006) 34(1) Journal of Law, Medicine and Ethics 85, 86.

52 Article 2 IHR 2005. Emphasis added.

${ }^{53}$ On securitisation see: T Balzacq, 'Preface' in Securitisation Theory: How security problems emerge and dissolve (Routledge 2011); M de Larrinaga and MG Doucet, Security and Global Governmentality (Routledge 2010).

${ }^{54}$ Articles 5 and 13 and Annex 1 IHR, and Article 6 and Annex 2 IHR.

${ }^{55}$ For example: WHO, Pandemic Influenza Risk Management (WHO 2017).
} 
Besides state parties the IHR 2005 also applies to the EU. ${ }^{56}$ This is reflected in the EU's key legal instrument relating to GPHS, which actually goes beyond disease, Decision 1082/2013/EU ${ }^{57}$ on serious cross-border threats to health. ${ }^{58}$ This instrument is founded upon and consistent with Article 168(5) TFEU, ${ }^{59}$ which reflects that EU competence in the public health field is complementary to that of its Member States ${ }^{60}$ (and who therefore have the main responsibilities ${ }^{61}$ ). The aforementioned obligation to ensure a high level of human health protection in the definition and implementation of EU policies and activities is referred to in and helps to underpin and justify the Decision. ${ }^{62}$ These provisions have been developed to embed GPHS within the EU's legal and constitutional framework and socio-political order. $^{63}$

The Decision is intended to strengthen surveillance and control, and coordination by providing a legal footing for the EU's Health Security Committee (HSC). The HSC was established in 2001 and is composed of representatives from EU Member State health ministries, the European Commission, the ECDC and the European Medicines Agency (which oversees the law and regulation relating to pharmaceuticals for human use). The ECDC ${ }^{64}$ lies at the heart of the EU's Early Warning and Response System (EWRS). The EWRS was established in $1999 .{ }^{65}$ After the adoption of Decision 1082/2013/EU the EWRS is defined as 'a rapid alert system for notifying at Union level alerts in relation to serious cross-border threats to health' and it is aimed at enabling 'the Commission and the competent authorities responsible at national level to be in permanent communication for the purposes of alerting, assessing public health risks and determining the measures that may be required to protect public health' ${ }^{66}$

Thus, much like action by the WHO, EU action centres on the gathering and production of scientific and technical knowledge as the basis for decision-making and periodic monitoring and evaluation. ${ }^{67} \mathrm{On}$ this basis public health threats are risks to be regulated and, as at the global level, preparedness is

\footnotetext{
${ }^{56}$ Article 57(1) IHR 2005 states the IHR and EU Treaties 'should be interpreted so as to be compatible'. Article 3(4) states that States Parties have 'the sovereign right to legislate and to implement legislation in pursuance of their health policies', and in so doing they should uphold the IHR.

${ }^{57}$ Recital 6 Decision 1082/2013/EU on serious cross-border threats to health and repealing Decision 2119/98/EC OJ L 293/1.

${ }^{58}$ These are defined by Article 3(g) Decision 1082/2013/EU, ibid, as 'a life- threatening or otherwise serious hazard to health of biological, chemical, environmental or unknown origin which spreads or entails a significant risk of spreading across the national borders of Member States, and which may necessitate coordination at Union level in order to ensure a high level of human health protection'.

${ }^{59}$ Article 168(5) TFEU.

${ }^{60}$ Article 6(a) TFEU - and it must be of 'added value' in order to comply with the principles of subsidiarity and proportionality under respectively Articles 5(3)-(4) Treaty on European Union (TEU).

${ }^{61}$ Article 168(7) TFEU provides that EU action shall 'respect the responsibilities of the Member States for the definition of their health policy...'.

${ }^{62}$ Recital 1 Decision 1082/2013/EU, note 57 above.

${ }^{63}$ European Commission, Programme of Cooperation on Preparedness and Response to Biological and Chemical Attacks [Health Security], G/FS D(2001) GG; European Commission, Strengthening Chemical, Biological, Radiological and Nuclear Security in the European Union - An EU CBRN Action Plan, COM(2009) 273 final; European Commission, Staff Working Document Bridging Security and Health: Towards the Identification of Good Practices in the Response to CBRN Incidents and the Security of CBR Substances, SEC(2009) 874.

${ }^{64}$ Established by Regulation (EC) 851/2004 establishing a European Centre for Disease Prevention and Control OJ L 142/1.

${ }^{65}$ Decision 2119/98/EC on a network for the epidemiological surveillance and control of communicable diseases OJ L 268/1.

${ }^{66}$ Article 8(1) Decision 1082/2013/EU, note 57 above. Emphasis added.

${ }^{67}$ Based on Article 168(2) TFEU and Article 168(7) TFEU. See: documents referred to in note 63 above and European Commission, 'Interim Document': Technical Guidance on Generic Preparedness Planning for Public Health Emergencies, 2005. The guidance includes checklists 'as a guide that may be used to assist in the development, revision or assessment of comprehensiveness of preparedness plans' (ibid, 3) and facilitates the 'inter-operability of national plans, mainly by the creation of co-ordination mechanisms and analysis and communication tools that enhance co-operation between key Member States and Commission players' (ibid, 2 , emphasis added).
} 
'directed towards identifying and addressing the current impact and subsequent threat potential [of a risk]....in order to limit its consequences ${ }^{, 68}$ - especially to the vitality of the economy. EU action was central to, for example, European planning and response to H1N1 in 2009. EU action was also an important part of the response to the outbreak of Ebola in west Africa that began in 2014. EU action encompassed 'political, financial and scientific resources to help contain, control, treat and ultimately defeat Ebola', ${ }^{69}$ and although the risk of transmission to the EU was low, the ECDC coordinated the exchange of information and preparedness. ${ }^{70}$ The two key technologies of global public health regulation I have outlined are also important for the wider process of governing - as I turn now to explain in the final part of the conceptual perspective.

\section{Risk regulation, socio-political order and projects of rule}

Risk thinking has become central not only to regulation but also to the very organisation of society, ${ }^{71}$ including in relation to determining priorities, allocating resources and enhancing efficiency of the regulatory process, and distributing responsibilities and accountabilities for blame in the event of failure. ${ }^{72}$ A related major contribution of science and technology studies (STS) is to highlight how risk and its related knowledges are 'incorporated into practices of state-making, or of governance more broadly'. ${ }^{73}$ Risk therefore provides a key way of auditing, verifying and legitimating regulatory technologies and its related socio-technical order and project of rule. ${ }^{74}$ Risk and its underpinning knowledges become even more important to these related aspects of governing in light of neoliberal political rationality. This rationality fuses governmentality with technical reason and means-end, instrumental, market rationality with the aim of optimising life. ${ }^{75} \mathrm{~A}$ key implication is the way in which knowledge is also increasingly entwined with, shaped by and made instrumental to power. In that regard, in the introduction to this article I made apparent the tightening relations between GPHS, including its underpinning form of knowledge, and the production and legitimation of the WHO's identity. But the WHO is one (albeit very important) site where GPHS operates: as I have mentioned, the technology operates in many sites, it is dominated by Western countries and is central to their respective and related socio-political orders and projects of rule, ${ }^{76}$ including as part of the notion of 'global health'. ${ }^{77}$

The wider importance of GPHS is also apparent at the EU level. Together for Health: A Strategic Approach for the EU 2008-2013, published in 2007, builds on and develops Article 168 TFEU $^{78}$ and

\footnotetext{
${ }^{68}$ European Commission, Pandemic Influenza Preparedness and Response Planning in the European Community, COM(2005) 607 final, 8 (emphasis added). Also see: European Commission, Communication on Strengthening Coordination on Generic Preparedness Planning for Public Health Emergencies at EU Level, $\operatorname{COM}(2005) 605$ final.

69 'EU Response to the Ebola Outbreak' https://ec.europa.eu/europeaid/regions/africa/west-africa/ebolaresponse_en (last accessed 7 August 2017).

${ }^{70}$ European Commission, The EU's Response to Help Fight the Ebola Outbreak in West Africa, MEMO/14/520, 5 September 2014

${ }^{71}$ In addition to the references to Beck and Giddens, note 24 above, see: U Beck, World Risk Society (Polity 2009); A Giddens, The Consequences of Modernity (Polity 1990).

${ }^{72}$ M Power, The Risk Management of Everything: Rethinking the politics of uncertainty (DEMOS 2004).

${ }^{73}$ Jasanoff, note 33 above, 3. See, more generally: PK Feyerabend, Against Method (Verso 1993); T Kuhn, The Structure of Scientific Revolutions, $2^{\text {nd }}$ edn (University of Chicago Press 1970); B Latour, Science in Action: How to follow scientists and engineers through society (Harvard UP 1988).

${ }^{74}$ J Black, 'The Emergence of Risk-Based Regulation and the New Public Risk Management in the United Kingdom' (2005) Public Law 512; M Power, The Audit Society (OUP 1997).

${ }^{75}$ See: Dean, note 29 above.

${ }^{76}$ For discussion, see: S Rushton, 'Global Health Security: Security for Whom? Security from What?' (2011) 59

Political Studies 779.

${ }^{77}$ D Fidler, SARS, Governance and the Globalisation of Disease (Palgrave Macmillan 2004); NK Poku and A Whiteside, Global Health and Governance: HIV/AIDS (Palgrave Macmillan 2004).

${ }^{78}$ European Commission, White Paper, Together for Health: A Strategic Approach for the EU 2008-2013, COM(2007) 630 final, 2. Emphasis added.
} 
has been approved by the European Council, ${ }^{79}$ purports to 'give direction to [EU] activities in health' ${ }^{80}$ Health emergencies are noted as one of the main challenges to be addressed by Together for Health. ${ }^{81}$ Significantly, the core principle of strengthening the EU's voice in global health in Together for Health figures EU 'responsibility regarding the health of citizens in third countries', including proactive action and a 'new focus... to tackle health threats within and outside the EU' ${ }^{82}$ Together for Health configures EU public health regulation and its priorities within the overarching goal of the Europe 2020 agenda: forging European integration through the optimal circulation of people and things within the internal market, ${ }^{83}$ growth and jobs. ${ }^{84}$ Overall, for both the WHO and the EU, the regulation of public health, including GPHS, is not an end in itself, but is tied to the production and public legitimation of their related and respective socio-political orders and projects of rule. ${ }^{85}$ In order to provide a bridge towards the discussion that follows, I turn now to outline the implications of the discussion thus far for the governed and their knowledges in decision-making.

\section{Marginalisation of 'on the ground' knowledges and the governed in decision-making}

Like any field of power/knowledge, those underpinning the risk-based technologies of prevention and and promotion as well as GPHS instantiate particular power relations, while also obscuring and naturalising and depoliticising them and their effects. ${ }^{86}$ Both of these technologies valorise scientifictechnical knowledge and those deemed to have the requisite expertise to produce and interpret it. In respect of GPHS the uncertain nature of its regulatory targets actually makes the available scientifictechnical knowledge and expertise more salient to decision-making; existing understanding and expertise become even more important to attempts at getting to know emerging threats so that they can be regulated.

Widening the sources of knowledge is likewise important, and that is reflected in strategies of two-way and multi-directional risk communication i.e. between regulators, scientists and those affected or 'at risk'. The IHR 2005 included an attempt to improve risk communication through the recognition of 'unofficial' sources of information (e.g. from news media and social networking) as the source for a declaration of a PHEIC by the WHO Director General. Nevertheless, the focus on biomedical approaches within GPHS appears to engender the centralisation and prioritisation of the biomedical aspects of public health problems over the existential aspects. This can be detrimental to the achievement of public health aims. ${ }^{87}$ Comments made in the Ebola Interim Assessment Panel report also bear this out. For instance, although engagement with local community leaders and their knowledges and expertise was noted as 'essential', ${ }^{88}$ it was not prioritised in the response to the Ebola outbreak despite the fact '[t]raditional cultural practices, including funeral and burial customs, contributed to virus transmission'. ${ }^{89}$ In other words, non-biomedical interventions such as behaviour

\footnotetext{
${ }^{79}$ Council of the EU, Council Conclusions on the Implementation of the EU Health Strategy - Outcome of Proceedings, Brussels, 20 November 2008.

${ }^{80}$ European Commission, note 78 above, 3 .

${ }^{81}$ Ibid, 3.

${ }^{82}$ European Commission, note 78 above, 8-9. Emphasis added. See further: European Commission, Combating HIV/AIDS within the European Union and in the Neighbouring Countries, 2006-2009, COM(2005) 654; European Commission, EU Strategy for Action on the Crisis in Human Resources for Health in Developing Countries, $\operatorname{COM}(2005) 642$.

${ }^{83}$ Article 26(2) TFEU defines the internal market as 'an area without internal frontiers in which the free movement of goods, persons, services and capital is ensured...'.

84 'Health strategy' http://ec.europa.eu/health/strategy/policy/index_en.htm.

${ }^{85}$ Cf. J Black, 'The Emergence of Risk-Based Regulation and the New Public Risk Management in the United Kingdom' (2005) Public Law 512.

86 This effect serves to remove or mask phenomena from comprehension of their 'historical emergence and from a recognition of the powers that produce and contour [them]' - see: W Brown, Regulating Aversion (Princeton UP 2006), 15. Emphasis added.

${ }^{87}$ For discussion, see: V Adams (ed), Metrics: What Counts in Global Health (Duke UP Books 2016).

${ }^{88} \mathrm{WHO}$, note 8 above, 20.

${ }^{89}$ Ibid.
} 
change and broad based social measures to tackle the determinants of disease and vulnerability were neglected.

The approach to the work undertaken in response to a medical emergency - delivering vertical 'magic bullet' interventions, performed on the basis of triage and driven by efficiency in order to contain the present threat at source - can, therefore, reflect and reinforce the underpinning power relations. Like wider forms of scientific-technical knowledge, and notwithstanding strategies to improve risk communication, the centrality of these knowledges to GPHS effectively marginalises and subordinates knowledges from 'on the ground' and those that produce and contribute them i.e. the governed. As Foucault put it, these knowledges 'have been disqualified...[as] naïve knowledges, hierarchically inferior knowledges, knowledges that are below the required level of erudition or scientificity'. ${ }^{90}$ Within biomedicine the dominance of scientific method and objectivity has often led to the discounting and sidelining of patients' views and experiences. ${ }^{91}$ As Kidd and Carel explain, biomedical approaches tend to have the effect of 'closing down opportunities for establishing sustained contact between a particular health professional and an individual patient, and for the rich forms of communicative relationship that might facilitate recognition and cultivation of patients' ability to contribute to the epistemic aspects of their care ${ }^{92}$ In other words, two-way risk communication can suffer.

The most prominent proposed reforms of GPHS would seem to perpetuate the latter - and that is, perhaps, not entirely surprising given that the reforms are often the products of expert-led initiatives..$^{93}$ There are, for instance, proposals to redesign or reconfigure the broader architecture of global health. ${ }^{94}$ Another proposal seeks to factor social justice into preparedness and response ${ }^{95}$ through the inclusion (and reframing) of global health security as a Sustainable Development Goals (SDG 18) ${ }^{96}$ Looking across the proposals, however, the central role of scientific-technical knowledge and experts in ensuring the resilience of essential infrastructures and the related power relations they establish and perpetuate remain largely unexamined. The upshot is that within GPHS and discussions on its reform, the epistemic capacity of those that are governed is limited, their 'on the ground' knowledges are sidelined and consequently their voices are silenced within decision-making processes.

Those governed by GPHS will either be ill or 'at risk' of becoming ill, and this makes them particularly vulnerable to marginalisation and silencing. There are of course other social positions (such as gender, race, sexuality and socio-economic position) that can intersect with and compound the vulnerability and silencing of the ill or 'at risk'. This has been the subject of discussion on social epistemology in philosophy. Fricker describes the latter kinds of silencing within social interactions and systems, including courts and science panels, as an 'epistemic injustice'. This is a 'wrong done to someone

\footnotetext{
${ }^{90}$ M Foucault, Society Must Be Defended (Penguin Books 2004), 7.

${ }^{91}$ E Fee and N Krieger, 'Understanding AIDS: Historical interpretations and the limits of biomedical individualism' (1993) 83 American Journal of Public Health 1477.

92 IJ Kidd and H Carel, 'Epistemic Injustice and Illness' (2017) 34(2) Journal of Applied Philosophy 172, 176. Emphasis added.

${ }^{93}$ For instance: S Moon and others, 'Will Ebola Change the Game? Ten Essential Reforms Before the Next Pandemic. The Report of the Harvard-LSHTM Independent Panel on the Global Response to Ebola' (2015) 386 The Lancet 2204.

${ }^{94}$ Gostin has been a particularly active proponent: LO Gostin, 'Global Health. Meeting Basic Survival Needs of the World's Least Healthy People: Toward a framework convention' (2008) 96(2) Georgetown Law Journal 331. The WHO has adopt just one international convention: Framework Convention on Tobacco Control (21 May 2003, entered into force 27 February 2005) 2301 UNTS 166. More recently see: LO Gostin, 'Our Shared Vulnerability to Dangerous Pathogens' (2017) 25(2) Medical Law Review 185.

${ }^{95} \mathrm{Cf}$. consideration of social justice in pandemic planning in: 'Bellagio Statement of Principles', available at: www.unicef.org/avianflu/files/Bellagio_Statement.pdf and www.bioethicsinstitute.org/web/page/905/sectionid/377/pagelevel/3/interior.asp (last accessed 7 August 2017). ${ }^{96}$ I Kickbusch and others, 'We Need a Sustainable Development Goal 18 on Global Health Security' (2015) (385) 9973 The Lancet 1069.
} 
specifically in their capacity as a knower' ${ }^{97}$ More particularly, those governed by GPHS seem to be subject to testimonial injustice, i.e. a form of injustice arises when individuals or groups lack credibility.

Those governed by GPHS, like other individuals and groups that are subject to epistemic injustice, are treated as the subjects of knowledge through 'top-down' or vertical interventions, including risk communication. In this way, then, the governed are, as Pohlhaus notes, 'relegated to the role of epistemic other': ${ }^{98}$ their epistemic capacities are reduced to those of providers of the factual information necessary to facilitate treatment, rather than wider forms of knowledge, and risk communication seems to be about enabling this. Intersecting with other forms of objectification, such as those that occur through the medical gaze (i.e. through the focus on their bodies),${ }^{99}$ instances of testimonial injustice place patients 'somewhere between an epistemic subject and object'. ${ }^{100}$ This refusal to accept that the information being provided by particular individuals or groups is relevant or significant can be linked to another: a refusal to reconsider the kinds of information that are legitimate within decision-making processes. ${ }^{101}$ The epistemic labour of those subject to GPHS is thereby constrained through its regulatory processes. This in turn effectively precludes any contribution to decision-making that might challenge the dominant forms of knowledge that underpin the regime, its design or interventions, and the distribution of responsibilities and accountabilities.

Similar themes have been explored by those working within the social studies of science and especially STS. Chiming with the notion of epistemic injustice, work within STS has noted that 'the technical is potentially political' and that participation by the governed through the contribution of their knowledges and perspectives makes sense only where there is injustice. ${ }^{102}$ In this regard, a key contribution of STS has been to challenge the 'deficit model' of those that are governed by scientific-technical institutions and systems that tended to inform understandings of risk communication as being one-way (from expert to the governed). STS has pointed out how this understanding of the governed as one-dimensional nonknowers is inaccurate. Scientific facts, their use and deployment have been noted as contingent ${ }^{103}$ and non-scientific knowledges are not necessarily less valid. Indeed, although individuals and diverse publics might not have full or complete understanding of particular scientific facts, these facts form part of a larger web of meaning and social understanding. Individuals know about diverse things in different ways, have a range of expertise, and are often reflexively aware of limitations to their comprehension of particular sociotechnical developments that they may actively seek to address. ${ }^{104}$

As such individuals and publics might feasibly contribute their knowledge, including on framing (i.e. GPHS), ${ }^{105}$ whom it hurts, whom it benefits, and how we might know, ${ }^{106}$ and how regulation should be

\footnotetext{
${ }^{97} \mathrm{M}$ Fricker, Epistemic Injustice: Power and the ethics of knowing (OUP 2007).

${ }^{98}$ G Pohlhaus, 'Discerning the Primary Epistemic Harm in Cases of Testimonial Injustice' (2014) 28(2) Social Epistemology 99, 107.

${ }^{99}$ M Foucault, The Birth of the Clinic (Tavistock 1976).

100 Pohlhaus, note 98 above.

${ }^{101}$ C Hookway, 'Some Varieties of Epistemic Injustice: Reflections on Fricker' (2010) 7 Episteme 151, 152.

102 A Moore, 'Beyond Participation: Opening up political theory in STS' (2010) 40(5) Social Studies of Science 793. This is a review of: MB Brown, Science in Democracy: Expertise, institutions and representation (MIT Press 2009).

${ }^{103}$ K Knorr Cetina, 'Laboratory Studies: The cultural approach to the study of science' in S Jasanoff and others (eds), Handbook of Science and Technology Studies (London 1995); Latour, note 73 above; M Lynch and S Woolgar (eds), Representation in Scientific Practice (MIT Press 1990); A Pickering (ed), Science as Practice and Culture (University of Chicago Press 1992).

${ }^{104}$ A Irwin and M Michael, Science, Social Theory and Public Knowledge (Open University Press 2003); A Kerr, S Cunningham-Burley, and A Amos, 'The New Genetics and Health: Mobilizing lay expertise' (1998) 7(1) Public Understanding of Science 41; BE Wynne, 'Knowledges in Context' (1991) 16 Science, Technology and Human Values 111; BE Wynne, 'Misunderstood Misunderstandings: Social identities and public uptake of science' (1992) 1 Public Understanding of Science 281.

${ }^{105}$ B Wynne, 'Risk as a Globalising "Democratic" Discourse? Framing Subjects and Citizens' in M Leach and others (eds), Science and Citizens: Globalisation and the challenge of engagement (Zed Books 2005).

106 S Jasanoff, 'Technologies of Humility: citizen participation in governing science' (2003) 41 Minerva 223; S Jasanoff, Designs on Nature (Princeton UP 2005), Ch 10 'Civic Epistemology'.
} 
reframed. ${ }^{107}$ These sorts of informational lacunae or blind spots are, perhaps, most likely to be detected from the perspective of those whose knowledge is excluded from current epistemic and decisionmaking practices. ${ }^{108}$ With this in mind, and by reference to the other conceptual points outlined above, I shall turn now to chart a way towards epistemic integration.

\section{Global public health security, risk, the governed and legitimation}

\section{Potential contribution of 'on the ground' knowledges by the governed}

The key starting point is appreciation of the way in which GPHS, like other fields of power/knowledge, engenders biopolitics i.e. space for attempts by those that are governed to demand or contest the exercise of power over life. ${ }^{109}$ The individuals and groups comprising the governed, and perhaps especially those that are affected or 'at risk' from public health threats, are obviously best placed to contribute their knowledges from 'on the ground' i.e. since these knowledges are 'theirs'. These knowledges might pertain to framing and the distortions in the distribution of resources away from health infrastructures and towards health emergencies, and vulnerability and encompass embodied ${ }^{110}$ and experiential knowledges. These can include direct experience of the impact of social position, culture, history and place in determining such matters as the effectiveness of GPHS and its biomedical interventions. Such knowledge and experience can also shed further light on the way in which GPHS skews attention and resources towards a focus on managing the consequences of medical emergencies. ${ }^{111}$

As I have already noted, in an apparent breakdown of risk communication, in respect of the outbreak of Ebola in 2014 the importance of 'on the ground' knowledges was realised within the infrastructures of GPHS only long after the initial outbreak. ${ }^{112}$ The Ebola Interim Assessment Panel quoted one community leader in Liberia:

'at first, there was confusion - we didn't know what Ebola was, what to do. We didn't know where to start; there were dead bodies in our houses; rumors about witchcraft. Then we organised ourselves, educated our community members about hand washing, touching, and how to handle the sick and the dead'. ${ }^{113}$

Far from being non-knowers or simply reservoirs of information for the practitioners of GPHS, individuals and groups in stricken communities demonstrated their epistemic capacities and exercised agency. Indeed, since many of these communities were not engaged with in the initial stages of the Ebola outbreak, or indeed later on, this is an example of the way in which the epistemic and institutional

\footnotetext{
${ }^{107}$ F Fischer, Reframing Public Policy: Discursive politics and deliberative practices (OUP 2003).

${ }^{108}$ Hookway, note 101 above, 158. Also see: A Wylie, 'Why Standpoint Matters' in S Harding (ed), The Feminist Standpoint Reader: Intellectual and political controversies (Routledge 2004).

${ }^{109}$ M Foucault, The Birth of Biopolitics: Lectures at the Collège de France, 1978-1979 (Palgrave Macmillan 2008). Cf. T Lemke, “The Birth of Biopolitics": Michel Foucault's lecture at the Collège de France on neoliberal governmentality' (2001) 30(2) Economy and Society 190. See further: M Dean, The Signature of Power: Sovereignty, governmentality and biopolitics (Sage 2013); A Lakoff, 'Two Regimes of Global Health' (2010) 1(1) Humanity 59.

${ }^{110}$ That is, knowledge on the inequalities producing death and ill health as found in bodies, see: N Krieger, 'Embodiment: A conceptual glossary for epidemiology' (2005) 59(5) Journal of Epidemiology and Community Health 350.

${ }^{111}$ As is the way in which this undermines efforts to combat address communicable and non-communicable diseases (NCD) and all threats to health. NCD are by far the biggest causes of morbidity and mortality worldwide e.g. over $80 \%$ of deaths in the WHO Europe region are attributable to (generally non-communicable) major and chronic diseases, see: R Busse and others, Tackling Chronic Disease in Europe (WHO 2010), 10. See further: LP Francis and others (eds), 'Pandemic Planning and Distributive Justice in Health Care' in M Freeman (ed), Law and Bioethics (OUP 2008); M Stevenson and M Moran, 'Health Security and the Distortion of the Global Health Agenda' in S Rushton and J Youde (eds), Routledge Handbook of Global Health Security (Routledge 2014).

${ }_{112}$ P Richards, Ebola: How a people's science helped end an epidemic (Zed Books 2016).

${ }^{113}$ WHO, note 8 above, 20. Emphasis added.
} 
failure of GPHS led to, and even forced, renewal of epistemic capacities 'on the ground' in ways that highlighted institutional failings and provided an opening for reform of the established regime.

This sort of 'bottom-up' engagement has been seen across contexts where risk and security dominate regulation. ${ }^{114}$ This includes through formal strategies of community engagement and attempts to elicit participation. ${ }^{115}$ These strategies are present in the public health context, such as HIV/AIDS action and breast cancer awareness, and they are one of the key characteristics of Gostin's influential notion of 'public health law'. Gostin explains that such strategies 'should result in stronger support for health policies and encourage citizens to take a more active role in protecting themselves and the health of their neighbours' ${ }^{116}$ In terms of more informal modes of engagement, activism in relation to HIV/AIDS is perhaps the most renowned example. For instance, ACT UP was successful in challenging the biomedical establishment so as to foster research on preventing and treating AIDS. ${ }^{117}$ Treatment regimes in the global South have also been modified in response to activism that demonstrated that treatment is possible in resource poor settings. ${ }^{118}$ And as terms such as 'citizen science' make clear, on the platform of new and cheaper information and communication technologies, citizens are increasingly involved in, catalysing and leading knowledge creation that supports new interventions in health. ${ }^{119}$

However, despite awareness of the importance of two-way and multi-directional risk communication practices, it is the capacity for understanding and action by the governed that has clearly yet to be fully developed, fostered and, if necessary, disciplined so that it can be rendered usable. The model of GPHS not only potentially under-estimates the knowledge of public health threats that those it governs may have, but it also reaffirms the technocratic rationalities that exclude them and creates informational lacunae. ${ }^{120}$ In spite of this, 'on the ground' knowledges could be mediated through the techniques and practices of the technocratic regime. This could occur, for example, by researchers in the field ${ }^{121}$ using anthropological, ethnographic and participatory approaches. ${ }^{122}$ Indeed, as the Ebola Interim Assessment Panel also noted:

\footnotetext{
${ }^{114}$ See, for example: A Crawford, 'Networked Governance and the Post-Regulatory State? Steering, Rowing and Anchoring the Provision of Policing and Security' (2006) 10(4) Theoretical Criminology 449.

${ }^{115}$ For discussion, see: Nuffield Council on Bioethics, Conducting Research and Innovation in the Context of Global Health Emergencies: What are the ethical challenges? (NCB 2016).

${ }^{116}$ LO Gostin, Public Health Law, ${ }^{\text {nd }}$ edn (University of California Press 2008), 18. Emphasis added.

${ }^{117}$ ACT UP (AIDS Coalition to Unleash Power) was particularly important among US activists that challenged the biomedical sciences and changed drug testing conventions and licensing to accelerate the development of anti-retrovirals. See: S Epstein, Impure Science (University of California Press 1996).

${ }^{118} \mathrm{H}$ Epstein, The Invisible Cure: Africa, the West, and the fight against AIDS (Farrar, Strauss and Giroux 2007); P Farmer, 'Introducing ARVs in Resource-Poor Settings: Expected and unexpected challenges and consequences', available at: quod.lib.umich.edu/c/cohenaids/5571095.0177.033?rgn=main;view =fulltext; WE Forbath with others, 'Cultural Transformation, Deep Institutional Reform, and ESR Practice: South Africa's Treatment Action Campaign' in LE White and J Perelman (eds), Stones of Hope : How African activists reclaim human rights to challenge global poverty (Stanford UP 2011).

${ }^{119}$ A Irwin, Citizen Science: A study of people, expertise, and sustainable development (Routledge 1995); B Prainsack, 'Understanding Participation: The "citizen science" of genetics' in P Prainsack and others (eds), Genetics as Social Practice (Ashgate 2014).

${ }^{120}$ For discussion, in the context of criminal justice, see: O'Malley, note 42 above. More broadly, in the context of health and safety and social work respectively, see: JD Fraiberg and MJ Trebilcock, 'Risk Regulation: Technocratic and Democratic Tools for Regulatory Reform' (1997) 43 McGill Law Journal 835; K Kemshall, 'Risk Rationalities in Contemporary Social Work Policy and Practice' (2010) 40(4) British Journal of Social Work 1247.

${ }^{121}$ V Das, 'Public Goods, Ethics, and Everyday Life: Beyond the boundaries of bioethics' (1999) 128(4) Daedalus 99.

${ }^{122}$ For example: A Catley and others, 'Participatory Epidemiology: Approaches, methods, experiences' (2012) 191(2) The Veterinary Journal 151; A Allepuz and others, 'Review of Participatory Epidemiology Practices in Animal Health (1980-2015) and Future Practice Directions' (2017) 12(1) PLOS ONE e0169198.
} 
'[s]ocial science expertise is critical to understanding local beliefs, behaviors and customs. These experts can inform those who are at the front line, enabling them to better understand the context and work more effectively with communities to change behavior'. ${ }^{123}$

The key point, then, is that 'on the ground' knowledges can be generated, they might need to be disciplined (further), and they can be - and need to be - integrated with classic epidemiological and biomedical knowledges by and within the epistemic community for use in decision-making. ${ }^{124}$

\section{Regulatory frameworks as resources for epistemic integration}

Nevertheless, as the discussion in STS, the wider social studies of science and philosophy demonstrates, the integration of 'on the ground' with scientific-technical knowledges remains problematic. The failure to engage 'on the ground' knowledges that was underscored in the Ebola Interim Assessment Panel's report is far from an isolated occurrence. The importance of 'on the ground' knowledges to understanding and formulating a response to Ebola was known long before the most recent and most publicised outbreak. ${ }^{125}$ Indeed, in 2003/2004 'on the ground' local experience of H5N1 became part of serious reflection among policymakers, albeit only when the emergency did not transpire. ${ }^{126}$ The 2009 outbreak of H1N1 saw a return to scientific-technical knowledge and antivirals as the dominant approach to pandemic response, as the report of the Parliamentary Assembly of the Council of Europe underscored. ${ }^{127}$

To borrow a phrase from Medina, it seems GPHS regulators 'have been trained not to hear or to hear only deficiently and through a lens that filters out the speaker's perspective ${ }^{128}$ - the speaker here being those with and articulating 'on the ground' knowledges. It seems that the potential contribution of the governed is being stymied by processes that not only render them as having limited discursive and epistemic capacities, but that thereby effectively silences them. In order to advance their biopolitical claims, the individuals and groups that comprise the governed must convince an epistemic community and/or regulators of the importance of their 'on the ground' knowledges. In addition to enduring testimonial injustice, the governed also seem to be made subject to hermeneutic injustice, which arises here because individuals or groups do not articulate through the conceptual resources that resonate with regulators, and that inform the lens through which they view reality, think and act. As Medina goes on to state, "if one exhibits a complete lack of "alertness or sensitivity" to certain meanings or voices, one's communicative interactions are likely to contain failures...for which one has to take responsibility'. ${ }^{129}$ This responsibility extends beyond individuals to communities and '[i]nstitutions and people in a position of power'. ${ }^{130}$

Yet, within the disciplines I have mentioned, the discussion on epistemic integration and responsibility for epistemic injustice(s) - epistemic responsibility - that flows from the framing of GPHS stops short of fully appreciating the salience of the regulatory framework itself. Regulatory frameworks play a key role in establishing, reflecting and (re)producing the social relations that silence and engender epistemic injustice. Yet, the very framing of regulatory frameworks, including of GPHS, naturalises, depoliticises

\footnotetext{
${ }^{123}$ WHO, note 8 above, 20. Emphasis added.

${ }^{124}$ PM Haas, 'Introduction: Epistemic communities and international policy coordination' (1992) 46 International Organisation 1.

${ }^{125}$ BS Hewlett and BL Hewlett, Ebola, Culture and Politics: The anthropology of an emerging disease (Wadsworth Books 2008).

${ }^{126}$ DU Pfeiffer and others, 'A One Health Perspective on HPAI H5N1 in the Greater Mekong Sub-Region' (2013) 36(3) Comparative Immunology, Microbiology and Infectious Diseases 309.

${ }^{127}$ P Forster, 'To Pandemic or Not? Reconfiguring Global Responses to Influenza' (2012) STEPS Working Paper 51.

128 J Medina, 'Hermeneutical Injustice and Polyphonic Contextualism: Social silences and shared hermeneutical responsibilities' (2012) 26(2) Social Epistemology 201, 217. Emphasis added.

${ }^{129}$ Ibid., 218. This responsibility is grounded in virtue theory. For discussion see: Fricker, note 96 above, and Medina, note 123 above.

${ }^{130}$ Ibid., 215.
} 
and masks their fabrication, and obscures that which produces (or contributes towards) a lack of alertness or sensitivity by regulators i.e. the regulatory framework itself. The framing in turn mediates and masks the epistemic responsibilities for, and the epistemic injustices that arise from, the lack of sensitivity shown by regulators to those individuals and groups that do not or cannot articulate their knowledges and perceptions in the correct register i.e. one that gets them noticed. Moreover, much discussion misses the significance of the regulatory framework in contributing towards the conditions by and through which it becomes possible (or not) to facilitate (risk) communication, and ensure the epistemic integration of 'on the ground' knowledges and the governed, on the one hand, with the knowledges and experts that are privileged by GPHS, on the other hand.

The importance of regulatory frameworks, their rationalities, logics and constitutive discourses, including law and human rights, in producing political culture is implied within the disciplines I have mentioned thus far. Within law and regulatory studies ${ }^{131}$ discussion has focused on the appropriate relationship between expert legal and regulatory reasoning and popular or lay understandings. ${ }^{132}$ Particular attention has been given to the shape and design of procedures for participation, and in light of the Aarhus Convention's innovations, ${ }^{133}$ this is especially apparent in environmental law. ${ }^{134}$ This focus is perhaps unsurprising in light of liberal accounts where democratic decision-making is delegated to trusted elites wielding scientific and technocratic knowledge and expertise. The focus on participatory procedures is especially apparent in situations where there is little possibility of substantive agreement and participation is essentially used to quell contestation, produce public legitimacy and maintain a functioning economy. ${ }^{135}$ Despite such acknowledgement, epistemic integration in decision-making is either given brief mention (notably (albeit) as one of the key characteristics of Gostin's notion of 'public health law' - as noted above), is less a focus these days (environmental law), or it remains largely untouched in mainstream law and regulatory studies engagement with public health.

However, across these related disciplines there has been little attention to the conceptual or hermeneutic resources that regulatory frameworks could provide in order to facilitate collective (societal and regulatory) understanding and communication of perspectives between the governed and regulators, and their epistemic integration as the basis for decision-making. In other words, there has been little attention to the hermeneutic resources available and that could be used by the governed to sensitise regulators to their hitherto subordinated and marginalised voices and perspectives. ${ }^{136}$ Moreover, within the disciplines I have noted, there has been little discussion of the way in which the regulatory frameworks create pitfalls for epistemic integration. Indeed, the contribution of valuable 'on the ground' knowledge can be frustrated by the risk governance process itself. As explained by Power, within riskbased governance accountability has become linked with organisation in a single logic through which democratic ideals 'are increasingly positioned within ideals for good governance of the risk analysis process.... ${ }^{137}$ Consequently, techniques for accountability become part of a broader process of

\footnotetext{
${ }^{131}$ Notably, participation rights have received growing attention. Most relevant to this article is the discussion within EU legal studies and global administrative law, see especially: J Mendes, Participation in EU Rulemaking: A rights-based approach (OUP 2011); C Harlow, 'Global Administrative Law: The quest for principles and values' (2006) 17(1) European Journal of International Law 187.

${ }^{132}$ In addition to O'Malley, note 42 above, and the references in note 120 above, see: $\mathrm{J}$ Waldron, Law and Disagreement (OUP 1999).

${ }^{133}$ UN Economic Commission for Europe, Aarhus Convention on Access to Information, Public Participation in Decision-Making and Access to Justice in Environmental Matters (adopted 25 June 1998, entered into force 30 October 2001) 2161 UNTS 447. Mentioned again in Chapter 6.

${ }^{134}$ See, generally: E Fisher, B Lange and E Scotford, Environmental Law: Text, Cases, and Materials (OUP 2013), especially Chapters 4, 5 and 13; M Lee, EU Environmental Law, Governance and Decision-Making, $2^{\text {nd }}$ edn (Hart 2013), Chapters 7 and 8. See further: S Yearley, 'Bridging the Science-Policy Divide in Urban AirQuality Management: Evaluating Ways to Make Models More Robust Through Public Engagement' (2006) 24(5) Environment and Planning C 701.

${ }^{135}$ For discussion, see: R Brownsword, Rights, Regulation and the Technological Revolution (OUP 2008), 128.

${ }^{136}$ In this vein see: N Fairclough, Language and Power, $2^{\text {nd }}$ edn (Routledge 2001).

${ }^{137}$ M Power, Organised Uncertainty (OUP 2007), 20. Emphasis added.
} 
rendering organisations auditable and inspectable. Such techniques 'are increasingly framed as an organizational strategy to manage public expectations', ${ }^{138}$ govern perceptions that might undermine regulation, and foster relegitimation.

As I turn to explain, the importance of risk to regulatory frameworks such as GPHS could help to make regulators responsible and accountable for their framing of GPHS and the attendant epistemic injustice(s). In the following, therefore, I aim to lay the foundations for technologies that could highlight lacunae in and pluralise the production of knowledge and expertise for GPHS. These technologies could, I shall suggest, introduce doubt and controversy into any view of the sufficiency of GPHS, its foundational knowledges and practices, ${ }^{139}$ improve the knowledge base for decision-making and, through this, the quality, effectiveness and legitimacy of the decisions made.

\section{Towards epistemic integration: risk regulation, two types of reflexivity and the significance of legitimation}

As I have already noted, the reports of both the Ebola Interim Assessment Panel and the Parliamentary Assembly of the Council of Europe generated institutional risks to the standing and reputation of GPHS actors, and thereby held them accountable for failures to meet their responsibilities. At the same time the reports also provided ways for GPHS actors to limit and manage those risks and, therefore, to maintain the production of legitimacy. In both cases the institutional or secondary risk of damage to institutional reputation reflexively drove a response to (future) societal risks (perhaps especially Ebola and pandemic influenza). ${ }^{140}$ Rothstein and others explain this dynamic as follows:

'the growing centrality of risk to regulation can be driven by the institutional risks of regulatory control and is characterised by the development of systematic and sophisticated reflexive use of the risk instrument as a defensible means for justifying the regulation of societal risks....Institutional risks...can become a category for control in their own right, if they cannot be reflexively handled by the management of societal risk'. ${ }^{141}$

A focus on institutional risks can bring attention to societal risks and shape approaches to them via changes to regulatory frameworks. In this way, then, the reports and the very responses to them underscored the potential to demand and contest decision-making and, therefore, for biopolitics.

Individuals, groups and institutions are, also as already noted, reflexive agents in that they monitor social reality, including societal risks, and on that basis may take action to (re)shape reality and even themselves. Risk society can conceivably become a regulatory society. ${ }^{142}$ Societal perception of failure to identify and/or manage societal risks can lead to demands and contestation and, in turn, institutional risks to standing or reputation. As Power explains managing institutional risk entails attempts at governing 'unruly perceptions' and maintaining the 'production of legitimacy in the face of these perceptions' ${ }^{143}$ Institutional risks, and the knowledges that underpin them, can generate doubt and controversy, or, in Medina's terms, 'epistemic friction' ${ }^{144}$ Importantly, the take up and pluralisation of knowledges in decision-making hinges on regulators' reflexive engagement with and monitoring of

\footnotetext{
${ }^{138}$ Ibid, 20-21. Emphasis added.

${ }^{139}$ Cf. M Leach and I Scoones, 'The Social and Political Lives of Zoonotic Disease Models: Narratives, science and policy’ (2013) 88 Social Science \& Medicine 10.

${ }^{140}$ More broadly, the use of risk assessment in respect of highly unpredictable situations, including convicted criminals within the community, provides a way of reassuring the public - and, therefore, public legitimation of institutions - rather than actually protecting society. See: H Kemshall, Understanding Risk in Criminal Justice (McGraw-Hill 2003).

${ }^{141}$ H Rothstein and others, 'A Theory of Risk Colonisation: the spiralling regulatory logics of societal and institutional risk’ (2009) 35(1) Economy and Society 91, 103. Emphasis added.

${ }^{142}$ For discussion of risk as the basis for social activism, see: Beck, note 71 above.

${ }^{143}$ Power, note 137 above, 21. Emphasis added.

144 J Medina, The Epistemology of Resistance: Gender and racial oppression, epistemic injustice, and resistant imaginations (OUP 2012).
} 
social reality, and their sensitivity to institutional risks to standing and reputation. Provided the institutional risks are deemed important enough, or sufficiently threatening, the friction they generate could propel regulators to take up and integrate the underpinning knowledges within decision-making in an effort to shape public perceptions, manage institutional risks and maintain legitimacy.

The key point is that institutional risks can generate a 'way in' to decision-making and compel action to address them. Reflexivity is key to this 'way in' - and to summarise, two specific and linked types of reflexivity are central. First, the reflexivity of individuals and groups comprising the governed leading to the generation of institutional risks or claims grounded on new knowledge. Second, the reflexivity of regulators in responding to the institutional risks. ${ }^{145}$ Within public health itself reflexivity has been used in different ways to underpin specific techniques. In terms of GPHS, the rationality of preparedness planning and response makes use of reflexivity i.e. by governing population indirectly via essential infrastructures. Reflexivity is central to future preparedness planning, such as through the EU's 'pandemic 2009 evaluations and lessons learned' exercise. ${ }^{146}$

Engendering reflexivity and pluralising knowledges for decision-making is likewise resonant with strategies of two-way and multi-directional risk communication in preparedness planning, as well as in prevention and health promotion (and in wider risk regulation). Reflexivity underpins the latter techniques in that attention to them is used to govern ill health. Within closely related domains reflexivity also plays a central role. For example, in environment policy various designs of reflexive governance have been developed. ${ }^{147}$ Within EU law and policy-making, for example, reflexivity is not only integrated across these domains, it is also reflected in, for example, the 'better regulation' agenda, ${ }^{148}$ and techniques and processes such as impact assessment that aim to facilitate this (and other agendas and aims - like transparency, public legitimation and institutional risk management). ${ }^{149}$ In the health policy domain impact assessment involves a determination of the impact on health of proposals for new laws and policy. ${ }^{150}$

\section{Building supplementary technologies: reflexivity, human rights and institutional risk}

I seek to build upon these examples in order to develop the more specific understanding of reflexivity noted above into the rationality - see Figure: 1 - to underpin technologies that reframe, reimagine and reassemble various components in order to supplement GPHS. In order to generate the two types of reflexivity in particular (by individual and groups and by regulators), there must be a common starting point: a conceptual or hermeneutic resource, foundation and lens that can generate the two types of reflexivity and ensure the governed gain influence within decision-making. I work in broad brush strokes rather than close detail to highlight the way in which this lens could generate reflexivity and help to realise new possibilities for two-way risk communication, organisational learning and action. ${ }^{151}$

\footnotetext{
${ }^{145}$ Cf. CA Dunlop and CM Radaelli, ‘Systematising Policy Learning: From monolith to dimensions' (2013) 61 Political Studies 599.

146 'Pandemic 2009 Evaluations and Lessons Learnt' https://ecdc.europa.eu/en/seasonal-influenza/2009influenza-h1n1/pandemic-preparedness/evaluations (last accessed 7 August 2017).

147 These include adaptive management and its variants, which seeks to place environmental problems within the wider systems that produce them: L Rist and others, 'Adaptive Management: where are we now?' (2012) 40(1) Environmental Conservation 5. On the variants of AM, see: CS Holling (ed), Adaptive Environmental Assessment and Management (John Wiley and Sons 1978).

${ }^{148}$ See: 'Better regulation' https://ec.europa.eu/priorities/democratic-change/better-regulation_en\#documents (last accessed 7 August 2017).

${ }^{149}$ And for examples within the context of EU level GPHS, see: European Commission, Staff Working Document on Strengthening Chemical, Biological, Radiological and Nuclear Security in the European UnionAn EU CRBN Action Plan. Impact Assessment, SEC(2009) 790; European Commission, Staff Working Document on Strengthening Chemical, Biological, Radiological and Nuclear Security in the European UnionAn EU CRBN Action Plan. Summary of Impact Assessment, SEC(2009) 791.

${ }^{150}$ For discussion, see: Flear, note 17 above, Ch 2 'EU Public Health Governance', 56-63.

${ }^{151} \mathrm{Cf}$. M Leach and others, 'Governing Epidemics in an Age of Complexity: Narratives, politics and pathways to Sustainability' (2010) 20 Global Environmental Change 369.
} 
Looking back at the discussion in Section II, human rights seems the most prominent and likely candidate for the common starting point. Human rights is woven into the socio-political orders of both the WHO and the EU (and individual countries) and it is central to their legitimation. Human rights is of course a body of law. At the global level the right to health and related rights underpins and justifies interventions in public health, including GPHS. ${ }^{152}$ The body of law is essential to realising the right to health, as underlined in the WHO's recent report Advancing the Right to Health: The Vital Role of Law. ${ }^{153}$ Within the EU's legal and regulatory order the protection of health as underpinned by Article 35 EUCFR could be developed by reference to broader human rights norms. ${ }^{154}$ More than a body of law, human rights is also a discourse, a particular form of attention to the world, with its own way of thinking, articulating and responding that encompasses the practices and projects, the 'movements or groupings of lawyers, non-governmental organisations, and others who seek to secure and defend a particular right, group of rights, or human rights in general'. ${ }^{155}$ Human rights is probably the most successful and culturally resonant discourse internationally.

This is apparent in the articulation of demands for and contestation around issues of social justice, in the EU and globally. ${ }^{156}$ Indeed, human rights is widely recognised as an important form of attention to the world and register through which to frame and respond to injustice and unequal power relations, ${ }^{157}$ such as in the distribution of epistemic capabilities, and the benefits, risks and vulnerabilities produced by particular framings of issues. It is now widely recognised that 'promotion and protection of rights and health are inextricably linked' ${ }^{158}$ The influence of human rights and a marker of their success in global public health is found in the way in which, as one commentator puts it, it has been a 'gamechanger in how we think about health'. ${ }^{159}$ The importance of human rights is also borne out in discussions that it might even be supplanting bioethics in the regulation of health. ${ }^{160}$

More particularly, participation by the governed, including through the provision of their knowledge, is part of the process of human rights-based approaches to health-related decision-making, encompassing transparency and access to information, agency and the scope for social mobilisation and action. ${ }^{161}$ Participation is also linked to the outcome of a human rights-based approach, such as through

\footnotetext{
${ }^{152}$ See notes 36 and 37 above.

${ }^{153}$ R Magnusson, Advancing the Right to Health: The Vital Role of Law (WHO 2017).

${ }^{154}$ For instance, according to the Explanatory Notes for the EUCFR, note 40 above, Article 35 might be interpreted in light of Articles 11 and 13 European Social Charter (Revised) (3 May 1996, entered into force 1 July 1999) ETS 163. For discussion, see: TK Hervey and JV McHale, 'Article 35' in S Peers and others (eds), The EU Charter of Fundamental Rights (Hart 2015); O de Schutter, The European Social Charter in the Context of Implementation of the EU Charter of Fundamental Rights (Document Requested by the European Parliament Committee on Constitutional Affairs) (EU 2016).

${ }^{155}$ T Murphy, 'Repetition, Revolution, and Resonance' in T Murphy (ed), New Technologies and Human Rights (OUP 2009), 7.

${ }^{156}$ W Brown, States of Injury (Princeton UP 1995); W Brown, 'Suffering Rights as Paradoxes' (2000) 7 Constellations 230. In relation to health, see: JJ Amon, 'The "Right to Know" or "Know Your Rights"? Human Rights and a People-Centred Approach to Health Policy' in J Biehl and A Petryna (eds), When People Come First: Critical studies in global health (Princeton UP 2013).

${ }^{157}$ For example: AE Yamin, 'Suffering and Powerlessness: The significance of participation in rights-based approaches to health' (2009) 11(1) Health and Human Rights: An International Journal 5.

${ }^{158}$ JM Mann, 'Health and Human Rights: If not now, then when?' (1997) 2(3) Health and Human Rights 113.

${ }^{159}$ T Murphy, Health and Human Rights (Hart 2013), Ch 1 'Health and Human Rights', 30.

${ }^{160}$ R Ashcroft, 'Could Human Rights Supersede Bioethics?' (2010) 10(4) Human Rights Law Review 639.

${ }^{161}$ In human rights participation is mentioned in several instruments, for example: Committee on Economic, Social and Cultural Rights, 'General Comment No 12: The Right to Adequate Food (Article 11)' (12 May 1999) UN Doc E/C.12/1999/5; Article 28 Convention for the Protection of Human Rights and Dignity of the Human Being with regard to the Application of Biology and Medicine: Convention on Human Rights and Biomedicine (4 April 1997, entered into force 1 December 1999) ETS 164 (often referred to simply as the Oviedo Convention); Article 25 ICCPR. For further discussion, see: H Potts, 'Participation and the Right to the Highest Attainable Standard of Health' (University of Essex Human Rights Centre 2009); A Yamin, 'Suffering and
} 
mechanisms for distributing responsibilities, monitoring and holding to account, including beyond the legal sense. ${ }^{162}$ References to human rights have been used, and maintain the potential, to power discussion and ongoing questioning - in other words, reflexive engagement with social reality by individuals and groups. ${ }^{163}$ Thus, human rights is especially adept at denaturalising the framing of issues, such as GPHS. ${ }^{164}$

Linked to this human rights is firmly part of the repertoires of social movement activism on healthrelated matters - as, indeed, the examples of the contribution of knowledges from 'on the ground' noted above underscore. Social activists have had notable success in using human rights 'at least to disrupt...by challenging the language, the types of problem recognised...and the working methods of the public bioethics process'. ${ }^{165}$ In other words, resonant with what I said above, an actual or perceived breach of human rights can generate institutional risks to standing and reputation that demand action. ${ }^{166}$ 'On the ground' knowledges could generate, support and make possible human rights-based claims and, indeed, help to construct the lens through which they become apparent. ${ }^{167}$ Moreover, these claims could in turn generate institutional risks not only to standing and reputation, but also to the production and legitimation of organisational identity, socio-political order and projects of rule, and as such they would be even more cogent.

Of course, as discussed more extensively elsewhere, the use of human rights is not without paradoxes and pitfalls that might reproduce and reinforce epistemic injustice through the effective silencing of the governed. ${ }^{168}$ For instance, even as human rights promises and delivers results when deployed to combat social difference and its attendant injustices, it can also produce and reinforce social position as identity. Human rights can also depoliticise and naturalise the social origins of problems, and emphasise and abet moves towards self-management and individualisation that deny the potential of collective action to reshape governance. In these kinds of ways, human rights can narrow the discursive space available and within which problems can conceivably be recognised and framed and claims articulated. Nevertheless, human rights can generate reflexivity by individuals and groups comprising the governed and biopolitics.

In addition and closely related to this first type of reflexivity, human rights can generate the second type, i.e. reflexivity by regulators. This is essentially because human rights can get attention - and open doors. Human rights demands the attention and time of regulators. As one prominent human rights lawyer has observed, '[r]ights talk buys ten minutes of their attention. I use it like a magic wand' ${ }^{169}$ Human rights can persuade and convince regulators, ${ }^{170}$ and part of the reason is that it can present

Powerlessness: The Significance of Participation in Rights-Based Approaches to Health' (2009) 11(1) Health and Human Rights: An International Journal 5.

${ }^{162}$ P Hunt and G Backman, 'Health Systems and the Right to the Highest Attainable Standard of Health' (2008) 10(1) Health and Human Rights: An International Journal 81; A De Negri, 'A Human Rights Approach to Quality of Life and Health: Applications to public health programming' (2008) 10(1) Health and Human Rights: An International Journal 93.

${ }^{163}$ For discussion, see: Flear, note 17 above, Ch 6 'Citizen Participation in Governing'.

${ }^{164}$ L Lazarus and BJ Goold, 'Security and Human Rights: The search for a language of reconciliation' in BJ Goold and L Lazarus (eds), Security and Human Rights (Hart 2007); I Loader and N Walker, Civilising Security (CUP 2007); Ba Von Tigerstrom, Human Security and International Law: Prospects and problems (Hart 2007). ${ }^{165}$ Ashcroft, note 160 above, 640.

${ }^{166}$ Murphy, note 159 above, Ch 2 'Is Human Rights Prepared?'.

${ }^{167}$ Chiming with: P Farmer, 'Challenging Orthodoxies: The road ahead for health and human rights' (2008) 10(1) Health and Human Rights: An International Journal 5.

${ }^{168}$ M Flear and A Vakulenko, 'A Human Rights Perspective on Citizen Participation in the EU's Governance of New Technologies’ (2010) (10)4 Human Rights Law Review 661.

169 J Osborn, Harvard Law School and François-Xavier Bagnoud Center for Health and Human Rights Workshop, Economic and Social Rights and the Right to Health, September 1993, www.law.harvard.edu/programs/HRP/Publications/economic1.html http:/hrp.law.harvard.edu/wpcontent/uploads/2013/08/EconomicandSocialRightsandtheRighttoHealth.pdf, 8.

${ }^{170} \mathrm{~F}$ Fischer and H Gottweis (eds), The Argumentative Turn Revisited: Public policy as communicative practice (Duke UP 2012); G Majone, Evidence, Argument and Persuasion in the Policy Process (Yale UP 1992). 
institutional risks. ${ }^{171}$ Moreover, human rights can provide a common discursive and hermeneutic framework, which can, as Black explained, put 'the views of each set of participants [in governance] into a language that the others can understand' ${ }^{172}$ The perspective of those who articulate their 'on the ground' knowledges through the register of human rights seems more likely to be understood and far less likely to be dismissed or filtered out by regulators. Human rights based claims could be particularly compelling to regulators due to a point I have already noted: they present institutional risks to the production of organisational identity, socio-political orders and projects of rule. Such claims can more readily compete for and gain attention amongst the competing claims to address particular risks. ${ }^{173}$

Overall, human rights has the potential to facilitate the two types of reflexivity outlined above. Through the joint operation of the two types of reflexivity the governed have the potential to prompt the take up and integration of their knowledges - see Figure: 1 - with the dominant scientific-technical knowledges of decision-making, and thereby to restore their epistemic agency. This could lead to adjustments in the existing technologies of global public health (GHPS; prevention and health promotion). The mechanisms to facilitate epistemic integration (and leading to adjustments) could be modelled on, use or be built into the existing techniques of risk assessment, management and communication that comprise the cycle of preparedness planning and response. For example, monitoring and surveillance could seek out or be sensitive to 'on the ground' knowledges and especially those that (could) underpin human rights claims and institutional risks in 'real time' as a public health event is developing. The resulting data could feed into decisions on the kinds of harms or hazards to which risk to public health pertains and their prioritisation.

The related knowledges, claims and risks could also inform decisions on response and risk management, including on what constitutes reasonable use of the precautionary principle in responses, and the kinds of interventions chosen to deal with a certain risk profile. ${ }^{174}$ Post-event and during planning for the next cycle, evaluations exercises could pay more attention to these related knowledges, claims and risks. In this way the latter could form part of impact assessments and the 'lessons learned' built into revised plans and future responses. This could include attention to non-biomedical interventions for prevention and health promotion: behaviour change programmes and broad based social measures. Reflexivity (the two types of reflexivity and their dynamic relationship) could, in short, provide the rationality to (re)assemble components of the existing techniques of public health regulation into new technologies spanning and operating at various levels of decision-making: WHO, EU, national and, crucially, 'on the ground'.

\section{Conclusion}

In this paper, I have considered the limited role of 'on the ground' knowledges in GPHS and public health regulation more generally. I sought to cast fresh light on the salience of regulatory frameworks in producing the epistemic injustice endured by those that could contribute to these knowledges, and the potential of those selfsame frameworks in tackling that injustice. Through this analysis I have charted a way forward towards the integration of 'on the ground' knowledges with scientific-technical knowledges. I traced the key components of the technologies of global public health regulation, and GPHS in particular: the risk rationalities, related forms of knowledge and the actors that produce and interpret these knowledges. I highlighted both the scientific-technical framing of GPHS that underlies the lack of recognition of 'on the ground' knowledges and the silencing of those that could contribute to decision-making, and then how this engenders lacunae in the knowledge base for decision-making. In so doing, I have underscored the construction of GPHS and its significance, and explained the way

\footnotetext{
${ }^{171}$ See: Murphy, note 159 above, Ch 2 'Is Human Rights Prepared?'.

172 J Black, 'Regulation as Facilitation: Negotiating the genetic revolution' (1998) 61(5) Modern Law Review 621, 623. See further: J Habermas, The Theory of Communicative Action. Volume 1: Reason and the rationalisation of society (Polity 1986).

${ }^{173}$ Douglas and Wildavsky, note 43 above, 6.

${ }^{174}$ For discussion see: R Brownsword, Rights, Regulation and the Technological Revolution (OUP 2008), 118.
} 
in which the integration of 'on the ground' knowledges produced by those governed by this technology could improve its knowledge base, efficacy, accountability and legitimacy.

Why, then, has more not been done to ensure epistemic integration within GPHS' decision-making processes? What does this reveal about the actual function of the technology of GPHS? It seems that epistemic integration would challenge the technology, its design and the priorities built into it. A key role of GPHS, then, is to protect the Western countries that are its chief initiators and supporters, and, apparently, also its main beneficiaries. The epistemic integration that I have argued for in this article would involve bringing those that are governed within decision-making processes via their knowledges. Epistemic integration would seem to threaten the position of Western countries and undermine their interests in GPHS. GPHS essentially externalises, cordons off and manages threats, ${ }^{175}$ and thereby shifts the responsibility to deal with them i.e. the threats are something to be dealt with 'at source', typically in the global South. While these countries are allocated the main responsibility for dealing with public health threats, rich Western countries have more limited responsibility by acting at a distance. Although Western countries seem to act beneficently and ethically through the framework of GPHS, they actually act more out of self-interest and self-protection. Epistemic integration would seem to undermine the power and dominance of Western countries within GPHS and the global economy.

Epistemic integration of embodied and experiential knowledges within decision-making might also threaten to shed light on the limits of the extant technologies of global health. In particular, while techniques of prevention and health promotion are important, there are limits to their efficacy, not least the resources made available to them. This is, of course, partly due to state sovereignty, since it limits the scope for interventions within states by other states and external actors. But the broader organisation of the global economy also plays a key role in limiting the ability of the countries that are most vulnerable to public health threats to grow their economies and fund health infrastructures. This is not least because of the dominance of Western countries and their interests in the organisation of international trade, most notably, the World Trade Organisation. ${ }^{176}$ More deeply, epistemic integration would challenge modernist values on the import of empirically-derived knowledge and the salience of technological 'fixes' (like kits and pharmaceuticals) to the management of societal 'problems'. ${ }^{177}$ Public health knowledge thus becomes re-problematised: what public health knowledge is required in order to protect health so as to optimise the movement of people and things in the economy? To resist epistemic integration is, therefore, essentially to bolster extant power relations. As I have pointed out, these relations are actually antithetical to the protection of public health, and to the accountability and legitimacy of GPHS.

In order to foster epistemic integration and discussion of its potential and realisation, I have argued for the development of technologies of reflexivity. Specifically, I have reflected on the significance of risk regulation to GPHS and the actors that employ and operationalise it through their governance, and explained that this provides a 'way in' to decision-making by the governed and through which they might contribute their knowledges. Regulatory alertness and sensitivity to institutional risks to standing and reputation provide the 'way in'. This is particularly the case when, as I have suggested, the risks also threaten to undermine the wider process of governing: the production and legitimation of wider organisational identity, socio-political order and the related project of rule. Regulatory frameworks also provide opportunities to generate these kinds of institutional risks and reflexivity by those governed by GPHS and regulators. Indeed, given the centrality of human rights to those frameworks, it seems most likely to serve as a lens and hermeneutic resource to both underpin reflexivity and animate the gathering and production of 'on the ground' knowledges by the governed, and ensure their articulation in terms

\footnotetext{
${ }^{175}$ Exclusion - akin to externalisation - is one main approach to risk management, whereas the other is inclusion: N Rose, 'Government and Control' (2000) 40 British Journal of Criminology 321.

${ }^{176}$ A central theme in: E Jackson, Law and the Regulation of Medicines (Hart 2012).

${ }^{177}$ R Brownsword and K Yeung (eds), Regulating Technologies: Legal futures, regulatory frames and technological fixes (Hart 2008); S Elbe, Security and Global Health: Toward the medicalisation of insecurity (Polity Press 2010); Jasanoff, note 1 above.
} 
that receive regulatory attention, reflexivity and integration in the knowledge base for decision-making, i.e. as human rights claims that generate institutional risks.

In proposing technologies of reflexivity, therefore, I refuse the way in which the extant technologies of (global) health regulation figure those they govern as possessing epistemic capacities that are of little use to its technocratic regimes. Indeed, to do otherwise would be to perpetuate forms of epistemic injustice and limit the epistemic responsibilities and accountabilities of those that frame the regulatory technologies in the first place. Thus, my goal throughout has been to suggest that it is an appreciation of those that are governed and regulators as reflexive agents, and the norms, values and the diverse and plural forms of knowledge constitutive of more democratic technologies and socio-political orders, that needs to be built into supplementary technologies of (global) health regulation. This challenges the dominance of the current technocratic means of regulating, and reimagines 'unruly' perceptions and knowledges as potentially supportive of the regimes and particularly GPHS, and its continued efficacy, accountability and legitimacy. 